Document downloaded from:

http://hdl.handle.net/10251/158243

This paper must be cited as:

De-Miguel-Molina, B.; Hervás Oliver, JL.; Boix Domenech, R. (2019). Understanding innovation in creative industries: knowledge bases and innovation performance in art restoration organisations. Innovation. 21(3):421-442.

https://doi.org/10.1080/14479338.2018.1562300

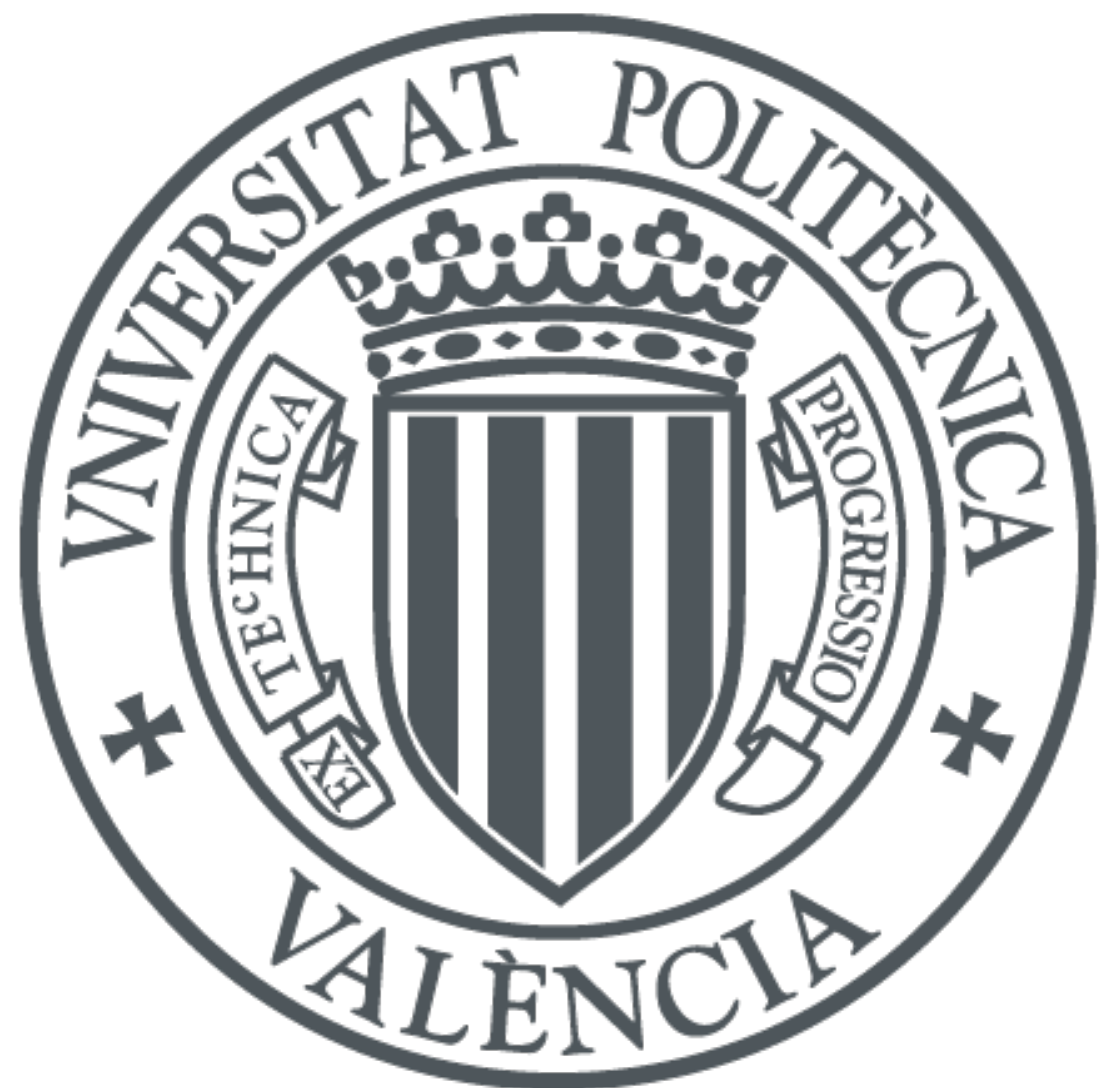

The final publication is available at

https://doi.org/10.1080/14479338.2018.1562300

Copyright Taylor \& Francis

Additional Information 
This is an Accepted Manuscript of an article published by Taylor \& Francis Group in INNOVATION: ORGANIZATION \& MANAGEMENT on 17/01/2019, available online: https://www.tandfonline.com/doi/full/10.1080/14479338.2018.1562300.

Please, cite as: De-Miguel-Molina, B., Hervás-Oliver, J.L., \& Boix, R. (2019) Understanding innovation in creative industries: knowledge bases and innovation performance in art restoration organisations. Innovation: Organization \& https://doi.org/10.1080/14479338.2018.1562300

\title{
Understanding innovation in creative industries: Knowledge bases and innovation performance in art restoration organisations
}

\author{
Blanca de-Miguel-Molina ${ }^{1 *}$, José-Luis Hervás-Oliver ${ }^{1,2,3}$ and Rafael Boix ${ }^{4}$ \\ ${ }^{1}$ Department of Management, Universitat Politècnica de València, Valencia, Spain \\ ${ }^{2}$ ESIC Business \& Marketing School, Spain \\ ${ }^{3}$ Corporación Universitaria de la Costa, CUC, Barranquilla, Colombia \\ ${ }^{4}$ Department of Applied Economics II-Economic Structure, Universitat de València, Valencia, \\ Spain \\ *Department of Management, Universitat Politècnica de València, Camino de Vera s/n, building \\ 7D, 46022 Valencia, Spain. Tel: +34 963877680. Fax: +34 963877689. Email: \\ bdemigu@omp.upv.es
}

This paper studies innovation in the creative industry of art restoration, which is characterised by an intensive use of symbolic knowledge. Using the resourcebased view of the firm as a theoretical framework, this study adapts Community Innovation Survey (CIS) methodology to this industry, creating and exploiting a unique dataset from the restoration departments of museums in 43 countries on 5 continents. The results suggest that the type and composition of the knowledge bases in play influence a department's absorptive capacity to access external information sources and thereby impact innovative outcomes. The article contributes to innovation literature by capturing innovation processes in a symbolic-based industry.

Keywords: innovation; creative industries; cultural industries; art restoration; symbolic-based industry; resource-based view; knowledge bases 
This is an Accepted Manuscript of an article published by Taylor \& Francis Group in INNOVATION: ORGANIZATION \& MANAGEMENT on 17/01/2019, available online: https://www.tandfonline.com/doi/full/10.1080/14479338.2018.1562300.

Please, cite as: De-Miguel-Molina, B., Hervás-Oliver, J.L., \& Boix, R. (2019) Understanding innovation in creative industries: knowledge bases and innovation performance in art restoration organisations. Innovation: Organization \& https://doi.org/10.1080/14479338.2018.1562300

\section{Introduction}

Little attention has been paid to understanding the processes that lead to innovation in artistic and creative activities, such as the so-called creative industries (CI). The latter are defined as "a set of knowledge-based activities, focused on but not limited to arts; they comprise tangible products and intangible intellectual or artistic services with creative content" (UNCTAD, 2010). They include activities such as publishing, fashion, the audio-visual sector, radio and TV, software, architecture and engineering, research and development, advertising, design, photography, the performing arts, artistic creation, museums, libraries and heritage (Howkins, 2007; UNCTAD, 2010; Nathan, Pratt, \& Rincon-Aznar, 2015).

This paper focuses on creative activities related to art restoration in museums. Using restoration departments as a unit of analysis of the NACE 90.03, this paper contributes to the literature on innovation by analysing the innovation process in CI linked to heritage and art restoration, disentangling its drivers and performance consequences and thereby unfolding the innovation potential of that industry, which is comprised of both public and private organisationally based teams of specialists embedded in diverse knowledge bases. Studying the knowledge bases of an industry involves matching skills to the tasks required by an occupation (Autor, Levy, \& Murnane, 2003).

Despite the growing importance and influence of CI in modern economies, our current understanding of innovation and innovative processes in these activities is extremely limited, particularly in creative and intangible activities such as those related 
This is an Accepted Manuscript of an article published by Taylor \& Francis Group in INNOVATION: ORGANIZATION \& MANAGEMENT on 17/01/2019, available online: https://www.tandfonline.com/doi/full/10.1080/14479338.2018.1562300.

Please, cite as: De-Miguel-Molina, B., Hervás-Oliver, J.L., \& Boix, R. (2019) Understanding innovation in creative industries: knowledge bases and innovation performance in art restoration organisations. Innovation: Organization \& https://doi.org/10.1080/14479338.2018.1562300

to art restoration. The Oslo Manual recognises that innovation exists in all activities (OECD 2005, section 3.1), and studies indicate that these cultural and creative industries perform similarly to other well-researched industries (manufacturing or services) in terms of organisational practices, developing innovation activities in a similar way that involves the creation, production, marketing and distribution of products, processes, techniques and ideas (see Lampel, Lant, \& Shamsie, 2000). The non-inclusion of artistic and creative industries in the NACE Rev.2 code 90 (creative, arts and entertainment activities), including NACE 90.03, art restoration, might be a consequence of the limited understanding of these industries.

The innovation activities of arts restoration departments are performed not only by fine arts experts or artists, but also by chemists, physicists, information technology professionals and engineers, among others, who technically and scientifically support the art restoration process. In fact, the Metropolitan Museum of Art in New York clearly separates curators from the scientists who work in conservation, calling the activities conducted by the restoration department "conservation" and "scientific research"1 ${ }^{1}$ Similarly, the Smithsonian Institution's restoration department emphasises the full set of high-tech restoration activities not conducted by artists or historians ${ }^{2}$ :

Instrumental support offerings include Fourier transform infrared spectroscopy (FTIR), gas chromatography-mass spectrometry (GC-MS), laser ablation ICP-MS, optical microscopy with image analysis (OM-IA), scanning electron microscopy with energy dispersive spectroscopy and wavelength dispersive spectroscopy (SEM-EDS-WDS), 3D scanning, ultraviolet-visible spectrophotometry (UV-VIS),

\footnotetext{
${ }^{1}$ https://www.metmuseum.org/about-the-met/conservation-and-scientific-research

2 https://www.si.edu/mci/english/research/technical_studies/index.html
} 
This is an Accepted Manuscript of an article published by Taylor \& Francis Group in INNOVATION: ORGANIZATION \& MANAGEMENT on 17/01/2019, available online: https://www.tandfonline.com/doi/full/10.1080/14479338.2018.1562300.

Please, cite as: De-Miguel-Molina, B., Hervás-Oliver, J.L., \& Boix, R. (2019) Understanding innovation in creative industries: knowledge bases and innovation performance in art restoration organisations. Innovation: Organization \& https://doi.org/10.1080/14479338.2018.1562300

xero-radiography, x-ray diffraction (XRD), x-ray fluorescence (XRF), and x-ray radiography....

This point is supported by data from the Australian Bureau of Statistics (2016), which includes these industries (arts and recreation services industries) in its innovation survey and reflects their importance to innovation by reporting that the innovative activity of acquisition of machinery, equipment or technology in that industry is higher $(49.5 \%)$ than the average of all industries $(44.5 \%)^{3}$. As we show in this study, these industries do create novelty ${ }^{4}$.

Knowledge bases of an industry are related to the skills required by an occupation (Autor, Levy, \& Murnane, 2003). Thus, the knowledge bases implied by employees reflect the systematisation and codification of usable knowledge that constitutes professionalisation (Rosenberg, 1976). Using knowledge bases as a critical construct to measure innovation capabilities in an industry, and following the Asheim and Hansen (2009) classification (analytic, synthetic, and symbolic), we use a resourcebased view of firms (RBV) and the knowledge-based view of the firm (KBV) (Kogut and Zander, 1992; Grant, 1996) to construct a theoretical framework from which to understand innovation drivers and performance in the art restoration industry. As

\footnotetext{
${ }^{3}$ http://www.abs.gov.au/AUSSTATS/abs@.nsf/DetailsPage/8158.02014-15?OpenDocument: Numbers denote the percentage of firms indicating innovation activity in the 2014-2015 period (see files of innovation expenditures, retrieved June 9, 2018). Other excluded activities from CIS are code 91 (libraries, archives, museums and other cultural activities) and code 93 (sports activities and amusement and recreation activities).

${ }^{4}$ There is strong evidence that museums continuously commercialise novelty. See for example Elster's (2013) study for WIPO, "Managing Intellectual Property for Museums", and several patents and restoration-related patents granted by museums in the European Patent Office, USPTO, WIPO-PCT and national patent offices.
} 
This is an Accepted Manuscript of an article published by Taylor \& Francis Group in INNOVATION: ORGANIZATION \& MANAGEMENT on 17/01/2019, available online: https://www.tandfonline.com/doi/full/10.1080/14479338.2018.1562300.

Please, cite as: De-Miguel-Molina, B., Hervás-Oliver, J.L., \& Boix, R. (2019) Understanding innovation in creative industries: knowledge bases and innovation performance in art restoration organisations. Innovation: Organization \& https://doi.org/10.1080/14479338.2018.1562300

mentioned, we argue that most of the skills embedded in restoration are distributed across different NACE codes, especially those involving engineering (synthetic) and scientific knowledge (analytic) that complements the typical curators' tasks and moves beyond the NACE 90.03, which claims that innovation does exist in the industry.

This research focuses on NACE 90.03, which includes art restoration and is very different from NACE 91.02, which covers the operations of museums and is not within our scope. Data were obtained from a worldwide survey of 167 museums in 43 countries, 90 of which had their own restoration departments. To follow accepted methodologies, our questionnaire and scales were based on the $\mathrm{CIS}^{5}$ and adapted to the art restoration sector. The results reveal that the innovation process of restoration departments differs little from those of CIS (manufacturing or service-based) industries. In showing this, our study makes a novel contribution to the literature by adapting CIS methodology to measure innovation in symbolic-intensive industries.

This paper is structured as follows. After this introduction, we summarise basic theories of innovation in CI: the resource-based view and knowledge bases construct. We then present an empirical study of the drivers of innovation in museum restoration departments. Our conclusions are found in the last section.

\section{Literature review: Innovation in creative and symbolic-intensive industries}

\footnotetext{
${ }^{5}$ The CIS surveys consulted were the Survey of Innovation in Enterprises (Spanish National Statistics Institute) and the CIS6 by the UK Department for Business, Innovation and Skills (http://webarchive.nationalarchives.gov.uk/20121204185119/http://www.bis.gov.uk/polici es/science/science-innovation-analysis/cis/cis6-questionnaire).
} 
This is an Accepted Manuscript of an article published by Taylor \& Francis Group in INNOVATION: ORGANIZATION \& MANAGEMENT on 17/01/2019, available online: https://www.tandfonline.com/doi/full/10.1080/14479338.2018.1562300.

Please, cite as: De-Miguel-Molina, B., Hervás-Oliver, J.L., \& Boix, R. (2019) Understanding innovation in creative industries: knowledge bases and innovation performance in art restoration organisations. Innovation: Organization \& https://doi.org/10.1080/14479338.2018.1562300

The literature on innovation in CI has answered three main questions: a) what does innovation mean in creative industries? (Gallenson, 2008; Stoneman, 2010); b) how innovative are these sectors? (Miles \& Green, 2008; Stoneman, 2010; Sunley, Pinch, Reimer, \& Macmillen, 2008; Martin-Rios \& Parga-Dans, 2016; Protogerou, Kontolaimou, \& Caloghirou, 2017); and c) how do knowledge bases influence innovation (Plum \& Hassink, 2014; Pina \& Tether, 2016)? This paper does not cover the empirical analysis of the second point because analysing differences among industries is not the aim of the paper.

Attempts to specifically contextualise innovation in the creative industries have yielded different terms. Stoneman (2010) created the "soft innovation" label for innovations concerned with changes in products (and perhaps processes) of an aesthetic or intellectual nature. Cappetta, Cillo and Ponti (2006) called "stylistic innovations" those that generated both a new product - from a physical point of view-and a new meaning. Alcaide-Marzal and Tortajada-Esparza (2007) used the term "aesthetic innovations" for products in which appearance is the most strongly perceived value and its main novelty. Cunningham and Higgs (2009) used the term "symbolic" to describe creative industries that create and exploit symbolic products and services, and Cappetta and Cillo (2008) supported the view that symbolic characteristics defined the creative industries, although their focus was on product rather than process innovation. Gallenson (2008) used the term "artistic innovation" for advances pushed by artists, which is similar to the type of innovation that Bakhshi and Throsby (2010) called "artform development". 
This is an Accepted Manuscript of an article published by Taylor \& Francis Group in INNOVATION: ORGANIZATION \& MANAGEMENT on 17/01/2019, available online: https://www.tandfonline.com/doi/full/10.1080/14479338.2018.1562300.

Please, cite as: De-Miguel-Molina, B., Hervás-Oliver, J.L., \& Boix, R. (2019) Understanding innovation in creative industries: knowledge bases and innovation performance in art restoration organisations. Innovation: Organization \& https://doi.org/10.1080/14479338.2018.1562300

Some studies indicate that the innovation outputs of some creative industries, such as the arts sectors, are below the national average (Müller, Rammer, \& Trüby, 2009; Chapain, Cooke, De Propris, MacNeill, \& Mateos-Garcia, 2010), while other researchers have found above-average innovation outputs in these industries (Bakhshi \& McVittie, 2009; Lee \& Rodríguez-Pose, 2014). Some authors suggest that arts organisations might have lower innovation outputs due to a lack of internal resources, including human resources, with which to engage in innovation (Camarero, Garrido, \& Vicente, 2011).

Additionally, the higher rates of innovation found by some studies refer to product, but not process, innovation. This is an important issue reflected in the terminology described because most of these terms referred to changes in product appearance and in most cases ignored processes (Sunley et al., 2008; Kloosterman, 2008; Protogerou et al., 2017). Although authors have characterised innovations in creative industries as aesthetic ones that present changes in the way a product is perceived as new or different (e.g. Alcaide-Marzal \& Tortajada-Esparza, 2007), not all innovations in creative industries are product innovations, and some of them are clearly related to processes. Moreover, statistics on arts and recreation activities (Australian Bureau of Statistics, 2016) indicate that these sectors innovate in products, processes, organisation and marketing. A similar result was obtained in an innovation measurement based on the CIS that considered all the operations undertaken by museums (Statistics Denmark, 2016), although this survey makes no reference to conservation and restoration activities. 
This is an Accepted Manuscript of an article published by Taylor \& Francis Group in INNOVATION: ORGANIZATION \& MANAGEMENT on 17/01/2019, available online: https://www.tandfonline.com/doi/full/10.1080/14479338.2018.1562300.

Please, cite as: De-Miguel-Molina, B., Hervás-Oliver, J.L., \& Boix, R. (2019) Understanding innovation in creative industries: knowledge bases and innovation performance in art restoration organisations. Innovation: Organization \& Management, https://doi.org/10.1080/14479338.2018.1562300

The third important question analysed in the literature concerns how knowledge bases influence innovation. Knowledge base construct states that knowledge bases are inputs in the creation of knowledge and innovation processes (Asheim, Boschma, \& Cooke, 2011). This construct considers three types of knowledge bases: analytic (science-based), synthetic (engineering-based) and symbolic (creativity-based) (Asheim \& Coenen, 2005; Asheim, 2007; Asheim \& Hansen, 2009).

The literature in this field has analysed which base predominates in which industries (Asheim \& Hansen, 2009; Pina \& Tether, 2016) and whether industries are characterised by a combination of bases (Moodysson, Coenen, \& Asheim, 2008; Klein, 2011; Tödtling \& Trippl, 2016). Research has found that the symbolic knowledge base is the primary base of creative industries because it produces symbolic outputs (Asheim, 2007; Asheim \& Hansen, 2009; Martin \& Moodysson, 2011). Works on knowledge bases in creative industries include studies on architecture (Pina \& Tether, 2016), music (Klein, 2011) and the media (Martin \& Moodysson, 2011).

Recent literature on knowledge bases has evolved to consider which combination generates the highest innovation output (Boschma, 2018). For creative industries, studies have indicated that the most common combination is a fusion of symbolic and synthetic knowledge bases (Klein, 2011; Van Tuijl \& Carvalho, 2014). However, these works specify that a combination does not imply the equal importance of each base. They also indicate that the dominant base might change over time (Ingstrup, Jensen, \& Christensen, 2017). Studying combinations of bases is important 
This is an Accepted Manuscript of an article published by Taylor \& Francis Group in INNOVATION: ORGANIZATION \& MANAGEMENT on 17/01/2019, available online: https://www.tandfonline.com/doi/full/10.1080/14479338.2018.1562300.

Please, cite as: De-Miguel-Molina, B., Hervás-Oliver, J.L., \& Boix, R. (2019) Understanding innovation in creative industries: knowledge bases and innovation performance in art restoration organisations. Innovation: Organization \& https://doi.org/10.1080/14479338.2018.1562300

because they have been shown to increase the innovation performance of firms (Tödtling \& Grillitsch, 2015).

We have chosen to use art restoration to explain innovation in CI. This activity produces an eminently symbolic end product in which different knowledge bases come into play in process innovation. For example, electron microscopy, X-ray diffraction, micro-Raman spectroscopy and gas chromatography-mass spectrometry come together in processes to analyse and examine works of art (de-Miguel-Molina, de-MiguelMolina, Segarra-Oña, \& Peiró-Signes, 2012). These technologies require analytic knowledge (chemical and physical) and synthetic knowledge (engineering), which makes the combination of knowledge bases apparent. A synthetic knowledge base will support analytical and symbolic bases both in conservation and restoration. Conservation of artworks requires considering how indoor environmental conditions affect them, such as lighting, temperature, air quality and pollutants (Sharif-Askari \& Abu-Hijleh, 2018; Schito, Conti, \& Testi, 2018). Therefore, constant monitoring of the indoor environment is required, as is developing solutions like sensors and software that assure that artworks are in the best environment to preserve them (Sharif-Askari \& AbuHijleh, 2018). Material engineers will help conservators and chemists in restoration processes when they need to analyse the response of, for example, wooden panels in paintings to changes in environmental conditions (Krzemień, Kot, \& Łukomski, 2018).

Two important conclusions can be inferred from this literature review. First, studies on CI have mainly centred on product innovation, and less attention is paid to process innovation, which is more relevant to the industry we analyse in this paper. The 
This is an Accepted Manuscript of an article published by Taylor \& Francis Group in INNOVATION: ORGANIZATION \& MANAGEMENT on 17/01/2019, available online: https://www.tandfonline.com/doi/full/10.1080/14479338.2018.1562300.

Please, cite as: De-Miguel-Molina, B., Hervás-Oliver, J.L., \& Boix, R. (2019) Understanding innovation in creative industries: knowledge bases and innovation performance in art restoration organisations. Innovation: Organization \& https://doi.org/10.1080/14479338.2018.1562300

second conclusion is that artwork restoration requires the complex integration or concurrence of symbolic, analytic and synthetic knowledge bases. In this study, we construct a framework to explain innovation in a symbolic-intensive industry through a chain of causes and effects that capture the processes and mechanisms of innovation.

\section{Integrating the resource-based view and knowledge bases: Hypotheses} development

In this sub-section, we combine knowledge bases construct with $\mathrm{RBV}$ to build a framework from which to state hypotheses.

Barney (1991) stated that RBV referred to all types of assets, organisational processes, knowledge capabilities and other potential sources of advantage. This organisational perspective (e.g. Barney, 1991; Peteraf, 1993) stresses that a firm's unique internal resources and capabilities determine its performance. The combinations of a firm's different assets or knowledge builds and configures a synergistic and complex higher-order capability to innovate that complements and reinforces each component, thereby forming interrelationships and complex integrations of diverse sources that are difficult to imitate and contributing to improving a firm's innovation capability and its performance (e.g. Rivkin, 2000; Teece, 2000; Teece, Pisano, \& Shuen, 1997). As Ennen and Richter (2010) suggested, therefore, competitive advantage not only results from developing resources but also from the capability to integrate them in a unique way, forming a complex set of capabilities to innovate. This approach is totally coherent with the knowledge-based view of the firm (Kogut \& Zander, 1992; Grant, 
This is an Accepted Manuscript of an article published by Taylor \& Francis Group in INNOVATION: ORGANIZATION \& MANAGEMENT on 17/01/2019, available online: https://www.tandfonline.com/doi/full/10.1080/14479338.2018.1562300.

Please, cite as: De-Miguel-Molina, B., Hervás-Oliver, J.L., \& Boix, R. (2019) Understanding innovation in creative industries: knowledge bases and innovation performance in art restoration organisations. Innovation: Organization \& https://doi.org/10.1080/14479338.2018.1562300

1996), in which the firm is conceptualized as an institution for integrating knowledge. Thus, organisational capability is the outcome of knowledge integration, linking organisational capability and competitive advantage. That knowledge integration requires creation and coordination. $\mathrm{As}$ in $\mathrm{RBV}$ and $\mathrm{KBV}$, a knowledge-bases perspective suggests that they will impact innovation performance, increasing it when unrelated variety is present, that is, when different knowledge bases are combined (Tödtling \& Grillitsch, 2015; Grillitsch, Martin, \& Srholec, 2017; Grillitsch, Schubert, \& Srholec, 2019).

We posit that in the arts restoration industry, the differing skills required to undertake the activity or knowledge bases deeply capture the resources and capabilities of the arts restoration units. Because the composition of the workforce (with its skills) reflects the type of knowledge bases that are important in an industry (e.g. Metcalfe, 2002), we argue that those knowledge bases (analytical knowledge is more akin to natural science, synthetic knowledge to engineering science and symbolic knowledge to the arts) define the stock capabilities and, therefore, the activities that an organisation can perform. For instance, whether a restoration unit includes chemists (with analytic knowledge) determines the range of activities focused on applying colour and decoration to paintings restored by fine arts employees (with symbolic knowledge).

These knowledge bases and, most importantly, their combinations and complementarities (Teece, 1986) make up the key repository of knowledge and capabilities of an organisation, that is, their resources and capabilities. When a company has limited skill resources, perhaps because it only has fine arts employees, the scope of 
This is an Accepted Manuscript of an article published by Taylor \& Francis Group in INNOVATION: ORGANIZATION \& MANAGEMENT on 17/01/2019, available online: https://www.tandfonline.com/doi/full/10.1080/14479338.2018.1562300.

Please, cite as: De-Miguel-Molina, B., Hervás-Oliver, J.L., \& Boix, R. (2019) Understanding innovation in creative industries: knowledge bases and innovation performance in art restoration organisations. Innovation: Organization \& https://doi.org/10.1080/14479338.2018.1562300

restoration activities is limited. However, when a firm has engineers and/or chemists (representing synthetic and analytic knowledge bases, respectively), then the fine arts activities (the symbolic knowledge base) can be upgraded thanks to the support provided by the skills from other knowledge bases.

These knowledge bases form complex capabilities from the synergistic complementarity obtained from their combination, reinforcing one another and thus forming a relationship between groups of activities that expands the repository of capabilities. Milgrom and Roberts (1995) point out, “...if the levels of any subset of activities are increased, then the marginal return to increases in any or all of the remaining activities rises". The power of this complementary effect was confirmed by Müller et al. (2009) in their study of Austrian creative industries. In particular, the point is that symbolic knowledge bases can be complemented by other available knowledge bases (analytical or synthetic), forming superior and complex capabilities to innovate.

Following this chain of thought, we state our first hypothesis in a testable manner.

H1: The existence of non-symbolic knowledge bases (analytic and/or synthetic) reinforces symbolic knowledge bases, forming complex and superior restoration capabilities that influence innovative performance.

As mentioned, a second aspect of a firm's internal resources is its absorptive capacity (AC) (Cohen \& Levintal, 1989, 1990), which provides an indication of the ability to access external sources of knowledge that may facilitate innovation. Absorptive capacity determines a firm's potential to search, access, integrate and exploit 
This is an Accepted Manuscript of an article published by Taylor \& Francis Group in INNOVATION: ORGANIZATION \& MANAGEMENT on 17/01/2019, available online: https://www.tandfonline.com/doi/full/10.1080/14479338.2018.1562300.

Please, cite as: De-Miguel-Molina, B., Hervás-Oliver, J.L., \& Boix, R. (2019) Understanding innovation in creative industries: knowledge bases and innovation performance in art restoration organisations. Innovation: Organization \& https://doi.org/10.1080/14479338.2018.1562300

knowledge that is external to the firm. Access to external sources of knowledge or search strategies (accessing information and knowledge from suppliers, customers, universities, etc.) is determined by a firms' absorptive capacity. Thus, a firm's internal resources generate an opportunity to use and exploit external knowledge and improve the capacity for innovation (e.g. Cohen \& Levintal, 1989, 1990; Lane \& Lubatkin, 1998; Voudouris, Lioukas, Iatrelli, \& Caloghirou, 2012; Zou, Ertug, \& George, 2018).

The relational view (Dyer \& Singh, 1998) argues that a firm's critical resources go beyond its boundaries and that inter-firm collaborative linkages generate further significant returns (Dyer \& Singh, 1998). External knowledge improves innovation capacity and can be found in sources such as customers, suppliers, competitors or universities and other public research organisations (Von Hippel, 1988; Katila \& Ahuja, 2002; Laursen \& Salter, 2006; Tödtling \& Grillitsch, 2013; Ahn, Kim, \& Moon, 2017; Zou, Ertug, \& George, 2018). All things being equal, the higher the access to external sources of knowledge, the better the learning effect and thus the innovative performance (Vlačić, Dabić, Daim, \& Vlajčić, 2019; Xie, Zou, \& Qi, 2018). Thus, in building on these findings to apply them to our particular industry, we expect that the existence of synthetic and analytic knowledge bases, the variety and number of skills and their associated capabilities constitute an ample knowledge platform from which to absorb external knowledge. For instance, when an art restoration firm includes physicists or chemists instead of only fine arts staff, the variety and amount of external knowledge that can be accessed and its combination with other different types of knowledge will lead to superior performance. Literature supports this view specifically in terms of the 
This is an Accepted Manuscript of an article published by Taylor \& Francis Group in INNOVATION: ORGANIZATION \& MANAGEMENT on 17/01/2019, available online: https://www.tandfonline.com/doi/full/10.1080/14479338.2018.1562300.

Please, cite as: De-Miguel-Molina, B., Hervás-Oliver, J.L., \& Boix, R. (2019) Understanding innovation in creative industries: knowledge bases and innovation performance in art restoration organisations. Innovation: Organization \& https://doi.org/10.1080/14479338.2018.1562300

creative industries. Chapain et al. (2010) in the software, film and media industries and Müller et al. (2009) and Sunley et al. (2008) for museums or performing arts have provided evidence of how the open character of these industries facilitates innovation.

Thus, the following hypothesis can be stated.

H2: Beyond symbolic ones, the existence of non-symbolic (analytic and/or synthetic) knowledge bases positively influences access to external sources of knowledge to innovate.

\section{Methodology}

An important limitation of studies of innovation in CI is that available databases are insufficient to address the topic. Moreover, there is no consensus on whether or how existing measurement frameworks such as the Community Innovation Survey could be adapted to the specificities of the creative industries (Handke, 2007; Alcaide-Marzal \& Tortajada-Esparza, 2007; Sunley et al., 2008; Miles \& Green, 2008; Stoneman, 2010; Chapain et al., 2010).

The museum activity analysed in this work - restoring works of art —is included in NACE 90 and is categorised within "creative, arts and entertainment activities". This activity is classified as creative by most institutional reports on the creative and cultural industries (e.g. UNCTAD, 2010; ESSnet-Culture, 2012; KEA European Affairs, 2006). Although some authors (e.g. Stam, Jong, \& Marlet, 2008) assume that the arts are less innovative because of their dependence on subsidies, innovation surveys for countries like Australia (Australian Bureau of Statistics, 2016) and Denmark (Statistics Denmark, 2016) indicate that the arts sector and museums undertake all types of innovation 
This is an Accepted Manuscript of an article published by Taylor \& Francis Group in INNOVATION: ORGANIZATION \& MANAGEMENT on 17/01/2019, available online: https://www.tandfonline.com/doi/full/10.1080/14479338.2018.1562300.

Please, cite as: De-Miguel-Molina, B., Hervás-Oliver, J.L., \& Boix, R. (2019) Understanding innovation in creative industries: knowledge bases and innovation performance in art restoration organisations. Innovation: Organization \& https://doi.org/10.1080/14479338.2018.1562300

(product, process, organisation and marketing). This paper focuses on process innovations.

\subsection{Data collection}

Data about innovation in museum restoration and conservation departments were obtained from a survey taken in 167 museums in 43 countries on 5 continents. The questionnaire $^{6}$ was adapted to museum restoration and conservation departments based on the CIS, which was created following the recommendations of the Oslo Manual (OECD/Eurostat, 2005). The CIS specifies the NACE codes to be used for the manufacturing and services sectors in the various countries surveyed but does not include creative industries (NACEs Rev.2: 90, 91, and 93). However, using CIS as a basis for our survey allowed us to apply different theoretical frameworks using the data. The latest CIS surveys include questions related to skills ${ }^{7}$, which could be a new springboard for examining the incorporation of different knowledge bases and its influence on innovation. Until this becomes a reality for every industry, our study offers a necessary step in this direction.

What does the conservation and restoration of artworks mean for a museum? It refers to activities museums undertake to preserve their artworks and continue exhibiting them to visitors (G. D. Lord \& B. Lord, 2009). For example, preventive

\footnotetext{
${ }^{6}$ The form of the questionnaire is accessible in this Zenodo community (https://zenodo.org/communities/ccis/?page $=1 \&$ size $=20$ ).

${ }^{7}$ Department for Business, Energy \& Industrial Strategy (2018).
} 
This is an Accepted Manuscript of an article published by Taylor \& Francis Group in INNOVATION: ORGANIZATION \& MANAGEMENT on 17/01/2019, available online: https://www.tandfonline.com/doi/full/10.1080/14479338.2018.1562300.

Please, cite as: De-Miguel-Molina, B., Hervás-Oliver, J.L., \& Boix, R. (2019) Understanding innovation in creative industries: knowledge bases and innovation performance in art restoration organisations. Innovation: Organization \& https://doi.org/10.1080/14479338.2018.1562300

conservation $^{8}$ in the Musée d'Orsay and Musée de L'Orangerie includes regular removal of dust from Monet's Water Lilies in the gallery in which it is displayed. This operation must be regularly undertaken because Monet did not varnish these paintings, and visitors carry dust into the galleries on their shoes. Conservation ${ }^{9}$ also includes using boxes and special glass coverings for the paintings to protect them during display and transportation to other museums. The process of art restoration starts with analyses that detect what restorations will be needed. These analyses are undertaken by interdisciplinary teams ${ }^{10}$ that include scientists from disciplines like chemistry, biology, physics, material sciences and polymer sciences.

The survey designed in our study aims to cover all the activities encompassed by conservation and restoration. For this purpose, our adaptation of the CIS was guided by advice from the conservation and restoration departments of some of the leading museums and restoration institutes from the sample. Once the survey was finished, it was sent to the directors of the conservation departments from the sample in two rounds between December 2010 and July 2011. We included replies received up to October 2011.

One of the inclusion criteria for museum departments in the sample was that the museums have paintings in their permanent collection because the study was part of a

\footnotetext{
${ }^{8}$ Musée d'Orsay, preventive conservation (http://www.museeorsay.fr/en/collections/restorations/restoration-policy-of-the-public-establishment-of-themusee-dorsay-and-musee-de-lorangerie.html\#c92521)

${ }^{9}$ Musée d'Orsay (http://www.musee-orsay.fr/en/collections/restorations/box-framing-forartworks.html)

${ }^{10}$ Victoria and Albert Museum (http://www.vam.ac.uk/content/articles/c/conservationdepartment/) and Metropolitan Museum of Art (https://www.metmuseum.org/about-themet/conservation-and-scientific-research/scientific-research/staff)
} 
This is an Accepted Manuscript of an article published by Taylor \& Francis Group in INNOVATION: ORGANIZATION \& MANAGEMENT on 17/01/2019, available online: https://www.tandfonline.com/doi/full/10.1080/14479338.2018.1562300.

Please, cite as: De-Miguel-Molina, B., Hervás-Oliver, J.L., \& Boix, R. (2019) Understanding innovation in creative industries: knowledge bases and innovation performance in art restoration organisations. Innovation: Organization \& https://doi.org/10.1080/14479338.2018.1562300

research project focused mainly on paintings. As a result, museums with no permanent collection or no paintings were excluded. The final population consisted of 900 museums in 43 countries, from which 167 responses were received, i.e. $18.55 \%$ of the sample, with an error margin of $6.8 \%$ (considering $50 \%$ heterogeneity and a confidence level of $95 \%$ ). Ninety museums had restoration and conservation departments and actively conducted restorations. The results in this paper come from these 90 departments.

\section{TABLE 1 NEAR HERE}

Of all the museums that answered the survey, 90 had a restoration and conservation department (53.9\%), and 77 did not (46.1\%). In 72 of the 90 positive cases, the department appeared in the museum's organisational chart, while in the remaining 18, it did not. Because the focus of the analysis was restoration and conservation, we included all 90 positive cases in the category "museum restoration and conservation departments" because all of them restored artworks.

An examination of the geographical location of the respondents showed that $60.7 \%$ of the museums in Europe had a restoration and conservation department, while the figure in the United States and Canada was 34.4\%, and in Asia, it was only $28 \%$. It should be noted that the form of the restoration sector varies between countries depending on the role of restoration institutes and specialised companies. 
This is an Accepted Manuscript of an article published by Taylor \& Francis Group in INNOVATION: ORGANIZATION \& MANAGEMENT on 17/01/2019, available online: https://www.tandfonline.com/doi/full/10.1080/14479338.2018.1562300.

Please, cite as: De-Miguel-Molina, B., Hervás-Oliver, J.L., \& Boix, R. (2019) Understanding innovation in creative industries: knowledge bases and innovation performance in art restoration organisations. Innovation: Organization \& Management, https://doi.org/10.1080/14479338.2018.1562300

One question in the survey asked what innovations the museum's restoration and conservation departments had implemented over the previous three years, the period recommended by the Oslo Manual (OECD/Eurostat, 2005). The innovation in restoration and conservation departments studied in this paper concerned processes, according to the definition of innovation types in the Oslo Manual (OECD/Eurostat, 2005).

We considered that the innovations concerning the displaying of works in exhibition halls (such as the use of, or response to, microclimates, light or mountings) are related to art conservation rather than marketing. As mentioned, displaying artworks is an activity that museums consider part of preventive conservation. Other types of innovation (such as organisational and marketing innovations) would have appeared in our responses if the survey had considered all the departments in a museum, which was not the aim of our research.

About $90 \%$ (81) of the museum restoration and conservation departments surveyed implemented some kind of innovation in restoration. The average innovation score for all 81 innovative restoration and conservation departments was 4.6 (out of 8 types of innovation; see Table 2). This figure is also the average for innovative European restoration and conservation departments, while it was 4.4 for innovative departments in the US and Canada.

\subsection{Variables}

To contextualise the CIS survey to the specificities of art restoration and to counter 
This is an Accepted Manuscript of an article published by Taylor \& Francis Group in INNOVATION: ORGANIZATION \& MANAGEMENT on 17/01/2019, available online: https://www.tandfonline.com/doi/full/10.1080/14479338.2018.1562300.

Please, cite as: De-Miguel-Molina, B., Hervás-Oliver, J.L., \& Boix, R. (2019) Understanding innovation in creative industries: knowledge bases and innovation performance in art restoration organisations. Innovation: Organization \& https://doi.org/10.1080/14479338.2018.1562300

Bakhshi and Throsby's (2010) point about the lack of a clear definition for innovation when applied to arts organisations, the survey sent to the museums ${ }^{11}$ defined innovation as:

- anything that involves an advance or improvement, whether it is incremental (involving small improvements) or radical (involving improvements that completely change the way in which works are examined and analysed, or the way processes of conservation and restoration are undertaken), which generates at least one of the following:

- an intermediate product (tools, technologies, or materials) that facilitates or enhances examination, analysis, conservation and restoration. Included are technological advances in other sectors, such as nano-technology, that can be used in restoration;

- an increase in the speed of examination, analysis, conservation and restoration. An example of this is a database that enables the swift identification of pictures and painters; and

- an increase in the quality or accuracy of the examination, analysis, conservation and restoration process. An example of this is the use of new systems for accurately identifying the age of a work or the composition of the mounting, substrate or colours (note that the innovation would be the new systems, not the "discovery" of the colours used by the artist).

\footnotetext{
${ }^{11}$ The form of the questionnaire designed is accessible in this Zenodo community (https://zenodo.org/communities/ccis/?page $=1 \&$ size $=20$ ).
} 
This is an Accepted Manuscript of an article published by Taylor \& Francis Group in INNOVATION: ORGANIZATION \& MANAGEMENT on 17/01/2019, available online: https://www.tandfonline.com/doi/full/10.1080/14479338.2018.1562300.

Please, cite as: De-Miguel-Molina, B., Hervás-Oliver, J.L., \& Boix, R. (2019) Understanding innovation in creative industries: knowledge bases and innovation performance in art restoration organisations. Innovation: Organization \& Management, https://doi.org/10.1080/14479338.2018.1562300

The innovation must be new or an improvement for the museum but need not be new in the sector or market. It does not matter whether the innovation was originally developed by one museum or by other museums, institutes or companies.

This definition links the information about process innovation in the CIS surveys with some examples of processes in the conservation and restoration of artworks. The first draft of the survey was reviewed via personal interviews with the directors of conservation departments of large Spanish museums and directors of important conservation institutes. The aim of the revisions was to confirm that the survey was clear and well adapted to the field of conservation and restoration.

Our model highlighted capabilities in the arts industry comprised of both internal resources (Milgrom \& Roberts, 1995; Stieglitz \& Heine, 2007; Hess \& Rothaermel, 2011) and combinations of internal and external resources (Chesbrough, 2003; Caloghirou, Kastelli, \& Tsakanikas, 2004; Cassiman \& Veugelers, 2006; Fu, 2012). The variables included the qualifications of specialists and types of knowledge bases (Caloghirou et al., 2004) and the capabilities of departments to restore (Caloghirou et al. 2004), which were considered internal resources. External information sources were included in the category of external resources (Caloghirou et al., 2004; Fu, 2012).

The variables (see Tables 2 and 3) were divided into innovation inputs and outputs and measured using questions from the survey created specifically for museum restoration and conservation departments. We based our variables on the theories covered in the literature review: RBV, KBV and knowledge bases. Data were presented 
This is an Accepted Manuscript of an article published by Taylor \& Francis Group in INNOVATION: ORGANIZATION \& MANAGEMENT on 17/01/2019, available online: https://www.tandfonline.com/doi/full/10.1080/14479338.2018.1562300.

Please, cite as: De-Miguel-Molina, B., Hervás-Oliver, J.L., \& Boix, R. (2019) Understanding innovation in creative industries: knowledge bases and innovation performance in art restoration organisations. Innovation: Organization \& Management, https://doi.org/10.1080/14479338.2018.1562300

in a scheme that included three groups of variables: internal knowledge inputs, external knowledge inputs and innovation outputs. Internal knowledge inputs included two separate sets of variables termed knowledge bases and restoration capabilities, while external knowledge measured the number of external sources of information.

The variable knowledge bases measured qualifications held by specialists working in museum restoration and conservation departments. The relevant question was, "What qualifications do the specialists who work in the restoration department have?" Eleven qualifications were included in the answers. In Table 2, qualifications are classified according to the knowledge-based approach described by Asheim and Hansen (2009) - i.e. symbolic (arts), analytic (science) and synthetic (engineering) bases. The objective of defining this variable was to analyse whether combining different knowledge bases would impact innovation, as stated in Hypothesis 1. According to the literature on knowledge bases, unrelated variety should increase innovation (Grillitsch et al., 2017; Grillitsch et al., 2019). In creative industries, this variety tends to include symbolic and synthetic bases (Klein, 2011; Van Tuijl \& Carvalho, 2014). In the sector analysed in this paper, we proposed that a combination of all three bases (symbolic, analytic and synthetic) would result in more innovation. The inclusion of the analytic base in the combination of the other two bases (symbolic and synthetic) is important from a theoretical perspective because it is considered the base that most impacts innovation (Pina \& Tether, 2016; Grillitsch et al., 2017; Grillitsch, et al., 2019).

The variable capabilities (for restoration) provided a way to measure the works that departments restored or were able to restore. The relevant question in the survey 
This is an Accepted Manuscript of an article published by Taylor \& Francis Group in INNOVATION: ORGANIZATION \& MANAGEMENT on 17/01/2019, available online: https://www.tandfonline.com/doi/full/10.1080/14479338.2018.1562300.

Please, cite as: De-Miguel-Molina, B., Hervás-Oliver, J.L., \& Boix, R. (2019) Understanding innovation in creative industries: knowledge bases and innovation performance in art restoration organisations. Innovation: Organization \& https://doi.org/10.1080/14479338.2018.1562300

was, "Which works in your museum does the department restore or can it restore?" Fifteen answers were included (see Table 2). RBV theory holds that unique internal capabilities will determine the performance of an organisation (Teece, 1986; Barney, 1991; Peteraf, 1993). Our model states that the knowledge bases in a museum will influence its capabilities to restore different artworks (such as easel paintings, mural paintings, sculpture, etc.). Moreover, complementarities between capabilities would positively impact innovation (Milgrom \& Roberts, 1995; Müller et al., 2009).

The variable external knowledge refers to the sources of external information used by museum restoration and conservation departments to obtain ideas that lead to innovation. Nine possible sources of information were listed (see Table 2), including universities and other research and development $(R \& D)$ institutions. This variable helps measure the existence in museums of absorptive capacity related to the conservation and restoration of artworks - that is, their ability to access external sources of knowledge that facilitate innovation (Cohen \& Levintal, 1989, 1990; Voudouris, Lioukas, Iatrelli, \& Caloghirou, 2012; Tödtling \& Grillitsch, 2013; Zou, Ertug, \& George, 2018).

The output variable innovation measures the types of innovation occurring in restoration and conservation departments. Eight innovations were defined (see Table 2) that consider the four phases of art conservation and restoration: examination, analysis, conservation and restoration. The division of innovations according to these phases was intended to clearly explain to curators what was meant by innovation in restoration and conservation (Bakhshi \& Throsby, 2010). The two hypotheses of this study will test 
This is an Accepted Manuscript of an article published by Taylor \& Francis Group in INNOVATION: ORGANIZATION \& MANAGEMENT on 17/01/2019, available online: https://www.tandfonline.com/doi/full/10.1080/14479338.2018.1562300.

Please, cite as: De-Miguel-Molina, B., Hervás-Oliver, J.L., \& Boix, R. (2019) Understanding innovation in creative industries: knowledge bases and innovation performance in art restoration organisations. Innovation: Organization \& https://doi.org/10.1080/14479338.2018.1562300

whether innovation in artworks restoration is positively influenced by knowledge bases (Grillitsch et al., 2017; Grillitsch et al., 2019), capabilities (Barney, 1991; Peteraf, 1993) and absorptive capacity (Cohen \& Levintal, 1989, 1990; Ahn, Kim, \& Moon, 2017; Zou, Ertug, \& George, 2018).

\section{TABLE 2 NEAR HERE}

\section{TABLE 3 NEAR HERE}

\subsection{Methods}

For the analysis, we consider the 90 museums that had restoration and conservation departments. First, we used experts from art restoration units to get content validity, seeking consensus for variables. Then we proceeded to get construct validity through structural equation modelling (SME), exploring also the predicted relationships or structure. SEM has been described as a combination of exploratory factor analysis and multiple regression (Ullman, 2001; Kline, 2005). The goal of SEM is to identify constructs using a set of manifest indicators and then to evaluate hypotheses regarding the relationships among the latent variables. SEM requires researchers to explicitly specify all characteristics of the hypothesized measurement model, that is, the theory that drives research. SEM does require that researchers have a strong conceptual foundation to guide the specification and evaluation of models. SEM encompasses two components: (a) a measurement model (essentially a confirmatory factor analysis 
This is an Accepted Manuscript of an article published by Taylor \& Francis Group in INNOVATION: ORGANIZATION \& MANAGEMENT on 17/01/2019, available online: https://www.tandfonline.com/doi/full/10.1080/14479338.2018.1562300.

Please, cite as: De-Miguel-Molina, B., Hervás-Oliver, J.L., \& Boix, R. (2019) Understanding innovation in creative industries: knowledge bases and innovation performance in art restoration organisations. Innovation: Organization \& https://doi.org/10.1080/14479338.2018.1562300

(CFA)) and (b) a structural model. SEM, therefore, is a sort of CFA and multiple regression. CFA includes scale validation and construct validation. Thus, SEM not only tests the structure (regressions) of the model, but also validates constructs. Although all questionnaires suffer from common-method variance, the use of SEM and its embedded CFA reduces significantly the common-method variance.

As most researchers agree, common-method variance is a potential problem in social research (Podsakoff, MacKenzie, Lee, \& Podsakoff, 2003). Harman's single factor test can be used as a technique to identify common-method variance. If a single factor emerges or one general factor will account for the majority of the covariance among the measures, then a substantial amount of common-method variance is present. For handling this potential problem, we argue that the questionnaire was based on the CIS methodology (OECD, 2005), which is a generally accepted method of measurement ${ }^{12}$. In addition, the confirmatory factor analysis within the SEM approach validates whether potential errors exist relating factor or constructs and covariance (Richardson, Simmering, \& Sturman, 2009). The SEM package was used within STATA 14.

In $\mathrm{H} 1$ and $\mathrm{H} 2$, the effect of the knowledge bases on innovation is not direct but mediated through two indirect mechanisms: the diversity of restoration capabilities (Equation 1) and the number of external sources of information (Equation 2).

Equation 2 combines both hypotheses in a SEM (Kline, 2005; Hancock et al., 2006), where $\alpha$ is the intercept, $\beta$ is the coefficient and $\varepsilon$ denotes the error term. The

\footnotetext{
${ }^{12}$ See works using CIS questionnaires such as Laursen and Salter (2006).
} 
This is an Accepted Manuscript of an article published by Taylor \& Francis Group in INNOVATION: ORGANIZATION \& MANAGEMENT on 17/01/2019, available online: https://www.tandfonline.com/doi/full/10.1080/14479338.2018.1562300.

Please, cite as: De-Miguel-Molina, B., Hervás-Oliver, J.L., \& Boix, R. (2019) Understanding innovation in creative industries: knowledge bases and innovation performance in art restoration organisations. Innovation: Organization \& https://doi.org/10.1080/14479338.2018.1562300

hypotheses are not independent, and in this context, an SEM provides an appropriate inference framework for mediation analyses that consider the correlation between the hypotheses and provide a more robust and efficient modelling framework than simple correlation or path analysis.

H1: $\quad$ Innovation $=\alpha_{1}+\beta_{1}$ Capabilities $+\varepsilon_{1}$

$$
\text { Capabilities }=\alpha_{2}+\beta_{2} \text { Knowledge Bases }+\varepsilon_{2}
$$

$\mathrm{H} 2: \quad$ Innovation $=\alpha_{3}+\beta_{3}$ External Knowledge $+\varepsilon_{3}$

External Knowledge $=\alpha_{4}+\beta_{4}$ Knowledge Bases $+\varepsilon_{4}$

$\mathrm{H} 1 \& \mathrm{H} 2: \quad$ Innovation $=\alpha_{1}+\beta_{1}$ Capabilities $+\gamma_{1}$ External Knowlede $+\varepsilon_{1}$

$$
\text { Capabilities }=\alpha_{2}+\beta_{2} \text { Knowledge Bases }+\varepsilon_{2}
$$

$$
\text { External Knowledge }=\alpha_{3}+\beta_{3} \text { Knowledge Bases }+\varepsilon_{3}
$$

Tests suggest a moderate excess of kurtosis in the data (prob $\left.\chi^{2}=0.017\right)$. Joint multivariate normality is not accepted (prob $\chi^{2}=0.000$ ). SEM is estimated using asymptotically distribution free (ADF) (Browne, 1984), which is a form of weighted 
This is an Accepted Manuscript of an article published by Taylor \& Francis Group in INNOVATION: ORGANIZATION \& MANAGEMENT on 17/01/2019, available online: https://www.tandfonline.com/doi/full/10.1080/14479338.2018.1562300.

Please, cite as: De-Miguel-Molina, B., Hervás-Oliver, J.L., \& Boix, R. (2019) Understanding innovation in creative industries: knowledge bases and innovation performance in art restoration organisations. Innovation: Organization \& https://doi.org/10.1080/14479338.2018.1562300

least squares and generalised least squares that does not require multivariate normality $^{13}$.

\section{Results}

\subsection{Description of results}

Figure 1 shows the results of the estimation with the unstandardized $(\beta)$ and standardized $\left(\beta_{z}\right)$ coefficients. The unstandardized coefficient shows the change in innovation output (dependent variable) due to an increase of one unit in an explanatory variable (knowledge bases, capabilities external information). Standardized coefficients have a mean of zero and unit variance and can be compared with independence of their scales. Standardized coefficients are interpreted as the average increase in the standard deviation of innovation with an increase of one standard deviation in an explanatory variable. The results support both hypotheses.

Hypothesis 1 states that a combination of knowledge bases enables specific capabilities that positively influence innovative output. The results show (see Figure 1) that the number of knowledge bases positively affects the capabilities to restore different artworks (standardized coefficient $\beta_{z}=0.60$, p-value $=0.000$ ), which in turn increases the innovative performance of museums $\left(\beta_{z}=0.22\right.$, $\mathrm{p}$-value $\left.=0.007\right)$.

Hypothesis 2 states that a second effect of the variety of knowledge bases is that they improve access to external sources of knowledge, which in turn are an asset to

\footnotetext{
${ }^{13}$ Estimates using maximum likelihood and quasi-maximum likelihood give almost similar results.
} 
This is an Accepted Manuscript of an article published by Taylor \& Francis Group in INNOVATION: ORGANIZATION \& MANAGEMENT on 17/01/2019, available online: https://www.tandfonline.com/doi/full/10.1080/14479338.2018.1562300.

Please, cite as: De-Miguel-Molina, B., Hervás-Oliver, J.L., \& Boix, R. (2019) Understanding innovation in creative industries: knowledge bases and innovation performance in art restoration organisations. Innovation: Organization \& https://doi.org/10.1080/14479338.2018.1562300

innovation in museums. The results (see Figure 1) support the contentions that knowledge bases increase access to and use of external information $\left(\beta_{z}=0.25\right.$, p-value $=0.012)$ and that external information improves innovation performance $\left(\beta_{z}=0.42, \mathrm{p}\right.$ value $=0.000)$.

Overall, an increase in one knowledge base other than the symbolic one indirectly increases the innovation output in museums by $121 \%$ (or by 0.245 standard deviations, with $\mathrm{p}=0.003$ ) (see Figure 1).

The model's goodness of fit is good according to a test of discrepancy $\left(\chi^{2}\right)$, baseline comparison (comparative fit index), size of the residuals (standardized root mean squared residual, coefficient of determination) and population error (root mean squared error of approximation) (see Figure 1).

An alternative model including a direct path from knowledge bases to innovation was tested, but the direct effect is not significant: the coefficient $(\beta=0.318)$ and comparable standardized coefficient are small $\left(\beta_{z}=0.064\right)$ and statistically nonsignificant $(\mathrm{p}=0.564)($ see Annex 2$)$. The full mediation model is also preferred to the partial mediation one according to model comparison using Akaike (1436.1 versus 1437.8) and BIC (1460.9 versus 1465.2) information criteria.

\section{FIGURE 1 HERE}

\subsection{Discussion of results}

The hypotheses measured how the combination of knowledge bases (unrelated variety) 
This is an Accepted Manuscript of an article published by Taylor \& Francis Group in INNOVATION: ORGANIZATION \& MANAGEMENT on 17/01/2019, available online: https://www.tandfonline.com/doi/full/10.1080/14479338.2018.1562300.

Please, cite as: De-Miguel-Molina, B., Hervás-Oliver, J.L., \& Boix, R. (2019) Understanding innovation in creative industries: knowledge bases and innovation performance in art restoration organisations. Innovation: Organization \& https://doi.org/10.1080/14479338.2018.1562300

impacts innovation in the conservation and restoration of artworks. This impact is also considered to be associated with the capabilities to restore artworks (through RBV) and access external knowledge (absorptive capacity).

Few studies have analysed combinations of knowledge bases in creative industries (Plum \& Hassink, 2014; Květoň \& Kadlec, 2018). Our results importantly indicate that the arts restoration industry does innovate. In addition, this process of innovation, according to our results, is not substantially different from that typically found in non-creative industries. Overall, our results suggest that this industry incorporates knowledge bases from other NACE codes that encompass knowledgeintensive skills typically found in R\&D or engineering activities (like knowledgeintensive business services). Contrary to those studies of creative industries that see only a combination of the symbolic and synthetic bases (Klein, 2011; Van Tuijl \& Carvalho, 2014), the restoration sector also incorporates the analytic base, and it is not residual. This base, identifiable because it uses scientific sources (Herstad, Aslesen, \& Ebersberger, 2014), has been suggested in the literature to be decisive for greater levels of innovation (Tödtling \& Grillitsch, 2015; Pina \& Tether, 2016). Therefore, our results indicate that combining the symbolic base with the synthetic and analytic generates more innovation.

The first hypothesis connected knowledge bases with capabilities (RBV) and capabilities with innovation. The second hypothesis linked knowledge bases with external knowledge and external knowledge with innovation. Our results indicate that as a consequence of incorporating non-symbolic-based skills, restoration departments that 
This is an Accepted Manuscript of an article published by Taylor \& Francis Group in INNOVATION: ORGANIZATION \& MANAGEMENT on 17/01/2019, available online: https://www.tandfonline.com/doi/full/10.1080/14479338.2018.1562300.

Please, cite as: De-Miguel-Molina, B., Hervás-Oliver, J.L., \& Boix, R. (2019) Understanding innovation in creative industries: knowledge bases and innovation performance in art restoration organisations. Innovation: Organization \& https://doi.org/10.1080/14479338.2018.1562300

are rich in analytic or/and synthetic knowledge bases outperform those that are not because they possess better capabilities and more access to external knowledge.

Considering results corresponding to the first hypothesis, a department's superior capabilities arise from going beyond symbolic knowledge bases and forming complex restoration capabilities through the integration of skills from engineering or chemistry, among many others. This complements and enriches the repository of capabilities and processes typically found in symbolic skills. Obtaining these capabilities is important because this industry creates novelty and commercialises restoration services to others, although commercialisation is not always its aim. The literature about knowledge bases has emphasised the small effect of the symbolic base when it acts alone (Pina \& Tether, 2016; Grillitsch et al., 2017). Our results go further and indicate that adding the other two knowledge bases will increase restoration capabilities and that these abilities will positively impact innovation.

With respect to the second hypothesis, our results indicate that combining knowledge bases will also positively influence access to external sources - that is, the absorptive capacity of the internal resources (Cohen \& Levintal, 1989, 1990). Moreover, our results confirm that absorptive capacity will improve innovation results (Cohen \& Levintal, 1989, 1990; Voudouris, Lioukas, Iatrelli, \& Caloghirou, 2012; Protogerou, Kontolaimou, \& Caloghirou, 2017). Therefore, when a department of conservation and restoration relies on analytic and synthetic bases in addition to the symbolic base, its members will have access to external sources of information, which will push their innovation output higher. 
This is an Accepted Manuscript of an article published by Taylor \& Francis Group in INNOVATION: ORGANIZATION \& MANAGEMENT on 17/01/2019, available online: https://www.tandfonline.com/doi/full/10.1080/14479338.2018.1562300.

Please, cite as: De-Miguel-Molina, B., Hervás-Oliver, J.L., \& Boix, R. (2019) Understanding innovation in creative industries: knowledge bases and innovation performance in art restoration $\begin{array}{lcc}\text { organisations. } & \text { Innovation: } & \text { Organization } \\ \text { https://doi.org/10.1080/14479338.2018.1562300 }\end{array}$

\& Management,

\section{Conclusions}

Focusing on the creative and symbolic knowledge-intensive industry and using an adaptation of the CIS methodology, this study has mapped innovation in art restoration by exploiting a unique dataset covering five continents. Using knowledge bases, represented by particular skills required in an organisation, as a central construct, we have built an RBV framework with which to capture innovation process in that industry.

Overall, our study extends knowledge on creative industries (e.g. Chapain et al., 2010; Sunley et al., 2008), bringing to the forefront of the literature three important contributions.

First, our results indicate that in this largely symbolic-based creative industry, the innovation process follows a similar pattern as that in other well-researched industries included in the CIS. Thus, our study opens up a debate concerning shifting the focus of research to symbolic-intensive industries not yet covered by the CIS.

Second, the construction of the framework, which proceeded by combining knowledge bases (skills) and the industry-specific drivers and outputs of innovation using a CIS-like methodology, allows capturing innovation patterns in a symbolic-based artistic industry, unfolding and revealing innovation potential. This methodological exercise can be adapted and replicated in other settings in the creative industries.

Third, building on Asheim et al. (2011), our study has provided an empirical application of classifying knowledge bases (analytic, synthetic and symbolic) based on the skills of an industry (e.g. Metcalfe, 2002), extending the literature by showing how 
This is an Accepted Manuscript of an article published by Taylor \& Francis Group in INNOVATION: ORGANIZATION \& MANAGEMENT on 17/01/2019, available online: https://www.tandfonline.com/doi/full/10.1080/14479338.2018.1562300.

Please, cite as: De-Miguel-Molina, B., Hervás-Oliver, J.L., \& Boix, R. (2019) Understanding innovation in creative industries: knowledge bases and innovation performance in art restoration organisations. Innovation: Organization \& https://doi.org/10.1080/14479338.2018.1562300

diverse the different mixtures of knowledge bases can be and how these compositions pay off.

Our results suggest that policymakers should investigate and assess innovation in industries beyond the well-researched areas established in the CIS. Given that policymakers actively participate in the management of museums in many regions of the world, they can repurpose this experience with innovation in museums to better understand innovation in other creative industries.

Lastly, this paper has some limitations, the most important being that causality is difficult to determine at a single point with quantitative data. Further steps are necessary to complement our analysis with qualitative research through case studies. Future studies should expand the results of this study into other industries and knowledge bases to analyse mainstream innovation.

\section{Acknowledgements}

The authors would like to thank the reviewers for their ideas, which helped improve the paper. They are also grateful for the feedback received from Prof. Björn Asheim and Prof. Sverre Herstad. We also would like to thank Prof. Barbara Hedderich (Hochschule Ansbach) for helping us collect data from some museums in Germany.

\section{Funding}

This work was supported by the Universitat Politècnica de València, Spain (Research Project $n$. 2677-UPV). 
This is an Accepted Manuscript of an article published by Taylor \& Francis Group in INNOVATION: ORGANIZATION \& MANAGEMENT on 17/01/2019, available online: https://www.tandfonline.com/doi/full/10.1080/14479338.2018.1562300.

Please, cite as: De-Miguel-Molina, B., Hervás-Oliver, J.L., \& Boix, R. (2019) Understanding innovation in creative industries: knowledge bases and innovation performance in art restoration organisations. Innovation: Organization \& Management, https://doi.org/10.1080/14479338.2018.1562300

\section{References}

Ahn, J.M., Kim, D., \& Moon, S. (2017). Determinants of innovation collaboration selection: a comparative analysis of Korea and Germany. Innovation: Organization \& Management, 19, 125-145.

Alcaide-Marzal, J., \& Tortajada-Esparza, E. (2007). Innovation assessment in traditional industries. A proposal of aesthetic innovation indicators. Scientometrics, 72, 33-57.

Asheim, B. (2007). Differentiated knowledge bases and varieties of regional innovation systems. Innovation: The European Journal of Social Science Research, 20, 223-241.

Asheim, B. T. \& Coenen L. (2005). Knowledge bases and regional innovation systems: Comparing Nordic clusters. Research Policy, 34, 1173-1190

Asheim, B., \& Hansen, H.K. (2009). Knowledge bases, Talents, and Contexts: On the Usefulness of the Creative Class Approach in Sweden. Economic Geography, $85,425-442$.

Asheim, B.T., Boschma, R., \& Cooke, P. (2011). Constructing regional advantage: Platform policies based on related variety and differentiated knowledge bases. Regional Studies, 45, 893-904.

Australian Bureau of Statistics. (2016). Innovation in Australian Business. Available at: http://www.abs.gov.au/ausstats/abs@.nsf/mf/8158.0

Autor, D., Levy, F., \& Murnane, R. (2003). The Skill Content of Recent Technological Change: An Empirical Exploration. Quarterly Journal of Economics, 118, 12791333.

Bakhshi, H., \& McVittie, E. (2009). Creative supply-chain linkages and innovation: Do the creative industries stimulate business innovation in the wider economy? Innovation: management, policy \& practice, 11, 169-189.

Bakhshi, H., \& Throsby, D. (2010). Culture of Innovation An economic analysis of innovation in arts and cultural organisations. NESTA. London, UK. Available at: www.nesta.org.uk/publications/culture-innovation. 
This is an Accepted Manuscript of an article published by Taylor \& Francis Group in INNOVATION: ORGANIZATION \& MANAGEMENT on 17/01/2019, available online: https://www.tandfonline.com/doi/full/10.1080/14479338.2018.1562300.

Please, cite as: De-Miguel-Molina, B., Hervás-Oliver, J.L., \& Boix, R. (2019) Understanding innovation in creative industries: knowledge bases and innovation performance in art restoration organisations. Innovation: Organization \& Management, https://doi.org/10.1080/14479338.2018.1562300

Barney, J. (1991). Firm resources and sustained competitive advantage. Journal of Management, 17, 99-120.

Boschma, R. (2018). A Concise History of the Knowledge Base Literature: Challenging Questions for Future Research. In A. Isaksen, R. Martin, \& M. Trippl (Eds.) New Avenues for Regional Innovation Systems - Theoretical Advances, Empirical Cases and Policy Lessons, pp. 23-40. Springer, Cham.

Browne, M.W. (1984). Asymptotically distribution-free methods for the analysis of covariance structures. British Journal of Mathematical and Statistical Psychology, 37, 62-83.

Caloghirou, Y., Kastelli, I., \& Tsakanikas, A. (2004). Internal capabilities and external knowledge sources: complements or substitutes for innovative performance? Technovation, 24, 29-39.

Camarero, C., Garrido, M.J., \& Vicente, E. (2011). How cultural organizations' size and funding influence innovation and performance: the case of museums. Journal of Cultural Economics, 35, 247-266.

Cappetta, R., \& Cillo, P. (2008). Managing integrators where integration matters: insights from symbolic industries. The International Journal of Human Resource Management, 19, 2235-2251.

Cappetta, R., Cillo, P., \& Ponti, A. (2006). Convergent designs in fine fashion: An evolutionary model for stylistic innovation. Research Policy, 35, 1273-1290.

Cassiman, B., \& Veugelers, R. (2006). In search of complementarity in innovation strategy: internal $\mathrm{R} \& \mathrm{D}$ and external knowledge acquisition. Management Science, 52, 68-82.

Chapain, C., Cooke, P., De Propris, L., MacNeill, S., \& Mateos-Garcia, J. (2010). Creative clusters and innovation. Putting creativity on the map. NESTA. London, UK. Available at: http://www.nesta.org.uk/publications/creativeclusters-and-innovation-report.

Chesbrough, H.W. (2003). The Era of Open Innovation. MIT Sloan Management Review, 44, 35-41. 
This is an Accepted Manuscript of an article published by Taylor \& Francis Group in INNOVATION: ORGANIZATION \& MANAGEMENT on 17/01/2019, available online: https://www.tandfonline.com/doi/full/10.1080/14479338.2018.1562300.

Please, cite as: De-Miguel-Molina, B., Hervás-Oliver, J.L., \& Boix, R. (2019) Understanding innovation in creative industries: knowledge bases and innovation performance in art restoration organisations. Innovation: Organization \& Management, https://doi.org/10.1080/14479338.2018.1562300

Cohen, W., \& Levintal, D. (1989). Innovation and learning - the two faces of R\&D. Economic Journal, 99, 569-596.

Cohen, W., \& Levintal, D. (1990). Absorptive capacity - a new perspective on learning and innovation. Administrative Science Quarterly, 35, 128-152.

Cunningham, S., \& Higgs, P. (2009). Measuring creative employment: Implications for innovation policy. Innovation: management, policy \& practice, 11, 190-200.

De-Miguel-Molina, B., de-Miguel-Molina, M., Segarra-Oña, M.V., \& Peiró-Signes, A. (2012). National And International Knowledge Transfers When Using Technology On The Conservation \& Restoration Of Paintings. International Business and Economics Research Journal, 11, 1493-1498.

Department for Business, Energy \& Industrial Strategy. (2018). The UK Innovation survey: Headline findings 2014 to 2016. Available at: https://assets.publishing.service.gov.uk/government/uploads/system/uploads/atta chment_data/file/700472/ukis_2017_headlines_final.pdf

Dyer, J., \& Singh, H. (1998). The relational view: cooperative strategy and sources of interorganizational competitive advantage. Academy of Management Review, 23, $660-679$.

Elster Pantaloni, R. (2013). Managing Intellectual Property for Museums. WIPO, Switzerland.

Ennen, E., \& Richter, A. (2010). The whole is more than the sum of its parts -or is it? A review of the empirical literature on complementarities in organizations. Journal of Management, 36, 207-233.

ESSnet-CULTURE. (2012). The ESSnet-Culture final report. Luxembourg. Available at: http://ec.europa.eu/culture/library/reports/ess-net-report_en.pdf

$\mathrm{Fu}, \mathrm{X}$. (2012). How does openness affect the importance of incentives for innovation? Research Policy, 41, 512- 523.

Gallenson, D.W. (2008). Analyzing Artistic Innovation: The Greatest Breakthroughs of the Twentieth Century. Historical Methods: A Journal of Quantitative and Interdisciplinary History, 41, 111-120. 
This is an Accepted Manuscript of an article published by Taylor \& Francis Group in INNOVATION: ORGANIZATION \& MANAGEMENT on 17/01/2019, available online: https://www.tandfonline.com/doi/full/10.1080/14479338.2018.1562300.

Please, cite as: De-Miguel-Molina, B., Hervás-Oliver, J.L., \& Boix, R. (2019) Understanding innovation in creative industries: knowledge bases and innovation performance in art restoration organisations. Innovation: Organization \& Management, https://doi.org/10.1080/14479338.2018.1562300

Grant, R.M. (1996). Toward a knowledge-based theory of the firm. Strategic Management Journal, 17, 109-122.

Grillitsch, M., Martin, R. \& Srholec, M. (2017). Knowledge Base Combinations and Innovation Performance in Swedish Regions. Economic Geography, 93, 458479.

Grillitsch, M., Schubert, T., \& Srholec, M. (2019). Knowledge base combinations and firm growth, Research Policy, 48, 234- 247.

Hancock, G. R., \& Mueller, R. O. ed. (2006). Structural Equation Modeling: A Second Course. Charlotte, NC: Information Age Publishing.

Handke, C. (2007). Surveying Innovation in the Creative Industries. 5th International EMAEE Conference on Innovation. Globalisation, Services and Innovation: The Changing Dynamics of the Knowledge Economy. Manchester (UK), 17 - 19 May.

Herstad, S. J., Aslesen, H. W., \& Ebersberger, B. (2014). On industrial knowledge bases, commercial opportunities and global innovation network linkages. Research Policy, 43, 495-504.

Hess, A.M., \& Rothaermel, F.T. (2011). When are assets complementary? Star scientists, strategic alliances, and innovation in the Pharmaceutical industry. Strategic Management Journal, 32, 895-909.

Howkins. J. (2007). The Creative Economy: How People Make Money From Ideas. Penguin, 2nd Edition. UK.

Ingstrup, M.B., Jensen, S., \& Christensen, P. R. (2017). Cluster evolution and the change of knowledge bases: the development of a design cluster. European Planning Studies, 25, 202-220.

Katila, R., \& Ahuja, G. (2002). Something old, something new: a longitudinal study of search behavior and new product introduction. Academy of Management Journal, 45, 1183-1194.

KEA European Affairs. (2006). The Economy of Culture in Europe (Brussels: European Commission Directorate-General for Education and Culture). Available at: http://ec.europa.eu/culture/library/studies/cultural-economy_en.pdf 
This is an Accepted Manuscript of an article published by Taylor \& Francis Group in INNOVATION: ORGANIZATION \& MANAGEMENT on 17/01/2019, available online: https://www.tandfonline.com/doi/full/10.1080/14479338.2018.1562300.

Please, cite as: De-Miguel-Molina, B., Hervás-Oliver, J.L., \& Boix, R. (2019) Understanding innovation in creative industries: knowledge bases and innovation performance in art restoration organisations. Innovation: Organization \& Management, https://doi.org/10.1080/14479338.2018.1562300

Klein, R. R. (2011). Where music and knowledge meet: a comparison of temporary events in Los Angeles and Columbus, Ohio. Area, 43, 320-326.

Kline, R. B. (2005). Principles and practices of structural equation modeling (2nd ed.). New York: Guilford Press

Kloosterman, R.C. (2008). Walls and bridges: knowledge spillover between 'superdutch' architectural firms. Journal of Economic Geography, 8, 545-563.

Kogut, B. \& Zander, U. (1992). Knowledge of the firm, combinative capabilities, and the replication of technology. Organization Science, 3, 383-397.

Krzemień, L., Kot, M., \& Łukomski, M. (2018). Stress Assessment in Artistic Materials Using a Micro-Scratching Technique. Experimental Techniques, 42, 473-479.

Květoň, V. \& Kadlec, V. (2018). Evolution of knowledge bases in European regions: searching for spatial regularities and links with innovation performance. European Planning Studies, DOI: 10.1080/09654313.2018.1464128.

Lampel, J., Lant, T., \& Shamsie, J. (2000). Balancing act: Learning from organizing practices in cultural industries. Organization Science, 11, 263-269.

Lane, P.J. \& Lubatkin, M. (1998). Relative absorptive capacity and interorganizational learning. Strategic Management Journal, 19, 461-477.

Laursen, K., \& Salter, A. (2006). Open for innovation: the role of openness in explaining innovation performance among U.K. manufacturing firms. Strategic Management Journal, 27, 131-150.

Lee, N., \& Rodríguez-Pose, A. (2014). Creativity, cities and innovation. Environment and Planning A, 46, 1139-1159.

Lord, G.D., \& Lord, B. (2009). The Manual of Museum Management, 2nd Edition. Altamira Press. USA.

Martin, R. \& Moodysson, J. (2011), Comparing knowledge bases: on the geography and organization of knowledge sourcing in the regional innovation system of Scania, Sweden. European Urban and Regional Studies, 20, 170-187.

Martin-Rios, C., \& Parga-Dans, E. (2016). The early bird gets the worm, but the second mouse get the cheese: non-technological innovation in creative industries. Creativity and Innovation Management, 25, 6-17. 
This is an Accepted Manuscript of an article published by Taylor \& Francis Group in INNOVATION: ORGANIZATION \& MANAGEMENT on 17/01/2019, available online: https://www.tandfonline.com/doi/full/10.1080/14479338.2018.1562300.

Please, cite as: De-Miguel-Molina, B., Hervás-Oliver, J.L., \& Boix, R. (2019) Understanding innovation in creative industries: knowledge bases and innovation performance in art restoration organisations. Innovation: Organization \& Management, https://doi.org/10.1080/14479338.2018.1562300

Metcalfe, J.S. (2002). Knowledge of growth and the growth of knowledge. Journal of Evolutionary Economics, 12, 3-15.

Miles, I., \& Green, L. (2008). Hidden innovation in the creative industries. NESTA, London. Available at: http://www.nesta.org.uk/publications/hidden-innovationcreative-industries.

Milgrom, P., \& Roberts, J. (1995). Complementarities and fit Strategy, structure, and organizational change in manufacturing. Journal of Accounting and Economics, 19, $179-208$.

Moodysson, J., Coenen, L., \& Asheim, B.T. (2008). Explaining spatial patterns of innovation: analytical and synthetic modes of knowledge creation in the Medicon Valley life-science cluster. Environment and Planning A, 40, 10401056.

Müller, K., Rammer, C., \& Trüby, J. (2009). The role of creative industries in industrial innovation. Innovation: Management, Policy \& Practice, 11, 148-168.

Nathan, M., Pratt, A., \& Rincon-Aznar, A. (2015). Creative economy employment in the EU and the UK. A comparative analysis. NESTA. London.

OECD/Eurostat. (2005). Oslo Manual: Guidelines for Collecting and Interpreting Innovation Data, 3rd Edition, The Measurement of Scientific and Technological Activities, OECD Publishing, Paris, https://doi.org/10.1787/9789264013100-en.

Peteraf, M.A. (1993). The cornerstones of competitive advantage: a resource-based view. Strategic Management Review, 14, 179-188.

Pina, K. \& Tether, B. S. (2016). Towards understanding variety in knowledge-intensive business services by distinguishing their knowledge bases. Research Policy, 45, 401-413.

Plum, O. \& Hassink, R. (2014). Knowledge bases, innovativeness and competitiveness in creative industries: the case of Hamburg's video game developers. Regional Studies, Regional Science, 1, 248-268.

Podsakoff, P. M., MacKenzie, S. B., Jeong-Yeon Lee, \& Podsakoff, N. P. (2003). Common Method Biases in Behavioral Research: A Critical Review of the 
This is an Accepted Manuscript of an article published by Taylor \& Francis Group in INNOVATION: ORGANIZATION \& MANAGEMENT on 17/01/2019, available online: https://www.tandfonline.com/doi/full/10.1080/14479338.2018.1562300.

Please, cite as: De-Miguel-Molina, B., Hervás-Oliver, J.L., \& Boix, R. (2019) Understanding innovation in creative industries: knowledge bases and innovation performance in art restoration organisations. Innovation: Organization \& Management, https://doi.org/10.1080/14479338.2018.1562300

Literature and Recommended Remedies. Journal of Applied Psychology, 88, 879-903.

Protogerou, A., Kontolaimou, A., \& Caloghirou, Y. (2017). Innovation in the European creative industries: a firm-level empirical approach. Industry and Innovation, 24, 587-612.

Richardson, H. A., Simmering, M. J., \& Sturman, M. C. (2009). A Tale of Three Perspectives: Examining Post Hoc Statistical Techniques for Detection and Correction of Common Method Variance. Organizational Research Methods, $12,762-800$.

Rivkin, J.W. (2000). Imitation of Complex Strategies. Management Science, 46, 824844.

Rosenberg, N. (1976). Perspectives on technology. Cambridge University Press.

Schito, E., Conti, P., \& Testi, D. (2018). Multi-objective optimization of microclimate in museums for concurrent reduction of energy needs, visitors' discomfort and artwork preservation risks. Applied Energy, 224, 147-159.

Sharif-Askari, H. \& Abu-Hijleh, B. (2018). Review of museums' indoor environment conditions studies and guidelines and their impact on the museums' artifacts and energy consumption. Building and Environment, 143, 186-195.

Stam, E., de Jong, J.P.J., \& Marlet, G. (2008). Creative industries in The Netherlands: structure, development, innovativeness and effects on urban growth. Geograkiska Annaler: Series B, Human Geography, 90, 119-132.

Statistics Denmark. (2016). Innovative workplaces in the public sector. Government sector: Museums. Available at: http://www.statbank.dk/OIN03DK

Stieglitz, N., \& Heine, K. (2007). Innovations and the role of complementarities in a strategic theory of the firm. Strategic Management Journal, 28, 1-15.

Stoneman, P. (2010). Soft innovation. Economics, product aesthetics, and the creative industries. Oxford University Press. UK.

Sunley, P., Pinch, S., Reimer, S., \& Macmillen, J. (2008). Innovation in a creative production system: the case of design. Journal of Economic Geography, 8, 675698. 
This is an Accepted Manuscript of an article published by Taylor \& Francis Group in INNOVATION: ORGANIZATION \& MANAGEMENT on 17/01/2019, available online: https://www.tandfonline.com/doi/full/10.1080/14479338.2018.1562300.

Please, cite as: De-Miguel-Molina, B., Hervás-Oliver, J.L., \& Boix, R. (2019) Understanding innovation in creative industries: knowledge bases and innovation performance in art restoration organisations. Innovation: Organization \& Management, https://doi.org/10.1080/14479338.2018.1562300

Teece, D.J. (1986). Profiting from technological innovation. Research Policy, 15, 285305.

Teece, D.J., Pisano, G., \& Shuen, A. (1997). Dynamic capabilities and Strategic Management. Strategic Management Journal, 18, 509-533.

Tödtling, F. \& Grillitsch, M. (2015). Does Combinatorial Knowledge Lead to a Better Innovation Performance of Firms? European Planning Studies, 23, 1741-1758.

Tödtling, F., \& Trippl, M. (2016). How do firms acquire knowledge in different sectoral and regional contexts? In: Shearmu, R., Carrincazeaux, C., \& Doloreux, D (Eds.) Handbook on the geographies of innovation. Edward Elgar Publishing, UK, pp. 142-154.

Ullman, J. B. (2001). Structural equation modeling. In B. G. Tabachnick \& L. S. Fidell (Eds.), Using multivariate statistics (4th ed.). Needham Heights, MA: Allyn \& Bacon.

UNCTAD. (2010). Creative Economy, Report 2010. Geneva: UNDP-UNCTAD. Available at: http://unctad.org/en/Docs/ditctab20103_en.pdf

Van Tuijl, E. \& Carvalho, L. (2014). Knowledge sourcing, knowledge bases, and the spatial organisation of car design. Environment and Planning A, 46, 1966 1982.

Vlačić, E., Dabić, M., Daim, T., \& Vlajčić, D. (2019). Exploring the impact of the level of absorptive capacity in technology development firms. Technological Forecasting \& Social Change, 138, 166-177.

Von Hippel, E. (1988). The sources of innovation. Oxford University Press. Oxford.

Voudouris, I., Lioukas, S., Iatrelli, M., \& Caloghirou, Y. (2012). Effectiveness of technology investment: Impact of internal technological capability, networking and investment's strategic importance. Technovation, 32, 400-414.

Xie, X., Zou, H., \& Qi, G. (2018) Knowledge absorptive capacity and innovation performance in high-tech companies: A multi-mediating analysis. Journal of Business Research, 88, 289-297.

Zou, T., Ertug, G., \& George, G. (2018). The capacity to innovate: a meta-analysis of absorptive capacity, Innovation: Organization \& Management, 20, 87-121. 
This is an Accepted Manuscript of an article published by Taylor \& Francis Group in INNOVATION: ORGANIZATION \& MANAGEMENT on 17/01/2019, available online: https://www.tandfonline.com/doi/full/10.1080/14479338.2018.1562300.

Please, cite as: De-Miguel-Molina, B., Hervás-Oliver, J.L., \& Boix, R. (2019) Understanding innovation in creative industries: knowledge bases and innovation performance in art restoration organisations. Innovation: Organization $\&$ Management, https://doi.org/10.1080/14479338.2018.1562300

Annex

HERE TABLE FOR ANNEX 1

HERE FIGURE FOR ANNEX 2 
This is an Accepted Manuscript of an article published by Taylor \& Francis Group in INNOVATION: ORGANIZATION \& MANAGEMENT on 17/01/2019, available online: https://www.tandfonline.com/doi/full/10.1080/14479338.2018.1562300.

Please, cite as: De-Miguel-Molina, B., Hervás-Oliver, J.L., \& Boix, R. (2019) Understanding innovation in creative industries: knowledge bases and innovation performance in art restoration organisations. Innovation: Organization \& Management, https://doi.org/10.1080/14479338.2018.1562300

\section{Tables}

Table 1. Summary of responses received and countries in which the museum restoration and conservation departments are located

\begin{tabular}{|c|c|c|c|}
\hline Continent & $\begin{array}{c}\text { Responses (number of } \\
\text { museums) }\end{array}$ & $\begin{array}{l}\text { Have restoration and } \\
\text { conservation } \\
\text { department and carry } \\
\text { out restorations } \\
\text { (number of museums) }\end{array}$ & Countries \\
\hline Europe & $\begin{array}{l}112 \text { from } 29 \text { countries } \\
(67 \%)\end{array}$ & 68 & $\begin{array}{l}\text { Austria, Belgium, Croatia, } \\
\text { Denmark, Estonia, Finland, } \\
\text { France, Germany, Greece, } \\
\text { Hungary, Iceland, Ireland, } \\
\text { Italy, Latvia, Lithuania, } \\
\text { Luxembourg, Netherlands, } \\
\text { Norway, Poland, Portugal, } \\
\text { Romania, Russia, Slovakia, } \\
\text { Slovenia, Spain, Sweden, } \\
\text { Switzerland, Turkey } \\
\text { (European area), United } \\
\text { Kingdom }\end{array}$ \\
\hline America & $\begin{array}{l}39 \text { from } 8 \text { countries } \\
(23 \%)\end{array}$ & 14 & $\begin{array}{l}\text { Argentina, Brazil, Canada, } \\
\text { Chile, Costa Rica, El } \\
\text { Salvador, Guatemala, United } \\
\text { States }\end{array}$ \\
\hline Asia & $\begin{array}{c}7 \text { from } 3 \text { countries } \\
(4 \%)\end{array}$ & 2 & $\begin{array}{c}\text { Japan, Republic of Korea, } \\
\text { Taiwan }\end{array}$ \\
\hline Africa & $\begin{array}{c}3 \text { from } 1 \text { country } \\
(2 \%)\end{array}$ & 3 & South Africa \\
\hline Oceania & $\begin{array}{c}6 \text { from } 2 \text { countries } \\
(4 \%)\end{array}$ & 3 & Australia, New Zealand \\
\hline
\end{tabular}

Compiled by the authors using data from the survey. 
This is an Accepted Manuscript of an article published by Taylor \& Francis Group in INNOVATION: ORGANIZATION \& MANAGEMENT on 17/01/2019, available online: https://www.tandfonline.com/doi/full/10.1080/14479338.2018.1562300.

Please, cite as: De-Miguel-Molina, B., Hervás-Oliver, J.L., \& Boix, R. (2019) Understanding innovation in creative industries: knowledge bases and innovation performance in art restoration organisations. Innovation: Organization \& https://doi.org/10.1080/14479338.2018.1562300

Table 2. Variables to determine innovation in restoration and conservation

\begin{tabular}{|c|c|c|c|c|}
\hline \multirow[t]{2}{*}{$\begin{array}{l}\text { Internal } \\
\text { knowledge } \\
\text { inputs }\end{array}$} & $\begin{aligned} & \text { Vari } \\
& 1 .\end{aligned}$ & $\begin{array}{l}\text { Knowledge } \\
\text { bases }\end{array}$ & \begin{tabular}{l}
\multicolumn{1}{c}{ Measure } \\
Q1. Fine arts...Symbolic Knowledge \\
Q2. Fine arts (specialising in \\
restoration)...Symbolic Knowledge \\
Q3. Conservation and restoration...Symbolic \\
Knowledge \\
Q4. Chemistry...Analytic Knowledge \\
Q5. Physics...Analytic Knowledge \\
Q6. Biology...Analytic Knowledge \\
Q7. Engineering...Synthetic Knowledge \\
Q8. History \\
Q9. Art history \\
Q10.Photography... Symbolic Knowledge \\
Q11.Other
\end{tabular} & $\begin{array}{l}\text { Values } \\
\text { First: presence of each } \\
\text { knowledge base: } \\
\text { - } \quad \begin{array}{l}\text { Symbolic knowledge: } \\
\text { value 1 (YES) or 0 (NO) }\end{array} \\
\text { - } \quad \begin{array}{l}\text { Analytic knowledge: } \\
\text { value 1 (YES) or 0 (NO) }\end{array} \\
\text { - } \quad \begin{array}{l}\text { Synthetic knowledge: } \\
\text { value 1 (YES) or 0 (NO) }\end{array} \\
\text { Then, count of knowledge } \\
\text { bases present: values from } 1 \\
\text { to } 3\end{array}$ \\
\hline & & $\begin{array}{l}\text { Restoration } \\
\text { capabilities }\end{array}$ & $\begin{array}{l}\text { W1. Easel painting } \\
\text { W2. Mural painting } \\
\text { W3. Gilding and altarpieces } \\
\text { W4. Polychrome sculpture } \\
\text { W5. Palaeontology } \\
\text { W6. Works in stone } \\
\text { W7. Textiles } \\
\text { W8. Metal and gold or silverware } \\
\text { W9. Ceramics } \\
\text { W10. Furniture } \\
\text { W11. Glass } \\
\text { W12. Photography } \\
\text { W13. Archive documents } \\
\text { W14. Film and video art } \\
\text { W15. Other }\end{array}$ & $\begin{array}{l}\text { Count of restoration } \\
\text { capabilities: values from } 0 \text { to } \\
15\end{array}$ \\
\hline $\begin{array}{l}\text { External } \\
\text { knowledge } \\
\text { inputs }\end{array}$ & 3. & $\begin{array}{l}\text { External } \\
\text { knowledge }\end{array}$ & $\begin{array}{l}\text { INF1. From museums } \\
\text { INF2. From professional associations } \\
\text { INF3. From conferences and seminars } \\
\text { INF4. From private R\&D institutes and } \\
\text { laboratories } \\
\text { INF5. From the Internet and specialised } \\
\text { websites } \\
\text { INF6. From public research centres } \\
\text { INF7. From machinery, materials, and } \\
\text { software suppliers } \\
\text { INF8. From scientific journals and } \\
\text { technical publications } \\
\text { INF9. From universities }\end{array}$ & $\begin{array}{l}\text { Count of sources of } \\
\text { information: values from } 0 \text { to } \\
9\end{array}$ \\
\hline $\begin{array}{l}\text { Innovation } \\
\text { outputs }\end{array}$ & & $\begin{array}{l}\text { Types of } \\
\text { innovations }\end{array}$ & $\begin{array}{l}\text { I1. In methods and instruments used to } \\
\text { examine and analyse art objects } \\
\text { I2. In products and reagents used to examine } \\
\text { and analyse art objects } \\
\text { I3. In techniques or procedures used in } \\
\text { restoration } \\
\text { I4. In tools or instruments used in restoration } \\
\text { I5. In consumables (glazes, solvents, } \\
\text { biocides, etc.) used in restoration } \\
\text { I6. In displaying works in exhibition halls (in } \\
\text { terms of the microclimate, light, } \\
\text { mounting, substrate, etc.) }\end{array}$ & $\begin{array}{l}\text { Count of types of innovation: } \\
\text { values from } 0 \text { to } 8\end{array}$ \\
\hline
\end{tabular}


This is an Accepted Manuscript of an article published by Taylor \& Francis Group in INNOVATION: ORGANIZATION \& MANAGEMENT on 17/01/2019, available online: https://www.tandfonline.com/doi/full/10.1080/14479338.2018.1562300.

Please, cite as: De-Miguel-Molina, B., Hervás-Oliver, J.L., \& Boix, R. (2019) Understanding innovation in creative industries: knowledge bases and innovation performance in art restoration organisations. Innovation: Organization \& https://doi.org/10.1080/14479338.2018.1562300

I7. In storing works in storage rooms

I8. In transporting works

Table 3. Partial correlations and statistical significance

Number of innovations Capabilities Knowledge bases External information

\begin{tabular}{|c|c|c|c|c|}
\hline Number of innovations & 1.0000 & & & \\
\hline Capabilities & $0.3608^{*}$ & 1.0000 & & \\
\hline Knowledge bases & $0.2917 *$ & $0.5728 *$ & 1.0000 & \\
\hline External information & $0.4913 *$ & $0.2762 *$ & $0.2685^{*}$ & 1.0000 \\
\hline
\end{tabular}

* statistically significant at $5 \%$. 
This is an Accepted Manuscript of an article published by Taylor \& Francis Group in INNOVATION: ORGANIZATION \& MANAGEMENT on 17/01/2019, available online: https://www.tandfonline.com/doi/full/10.1080/14479338.2018.1562300.

Please, cite as: De-Miguel-Molina, B., Hervás-Oliver, J.L., \& Boix, R. (2019) Understanding innovation in creative industries: knowledge bases and innovation performance in art restoration organisations. Innovation: Organization \& Management, https://doi.org/10.1080/14479338.2018.1562300

\section{Figure}

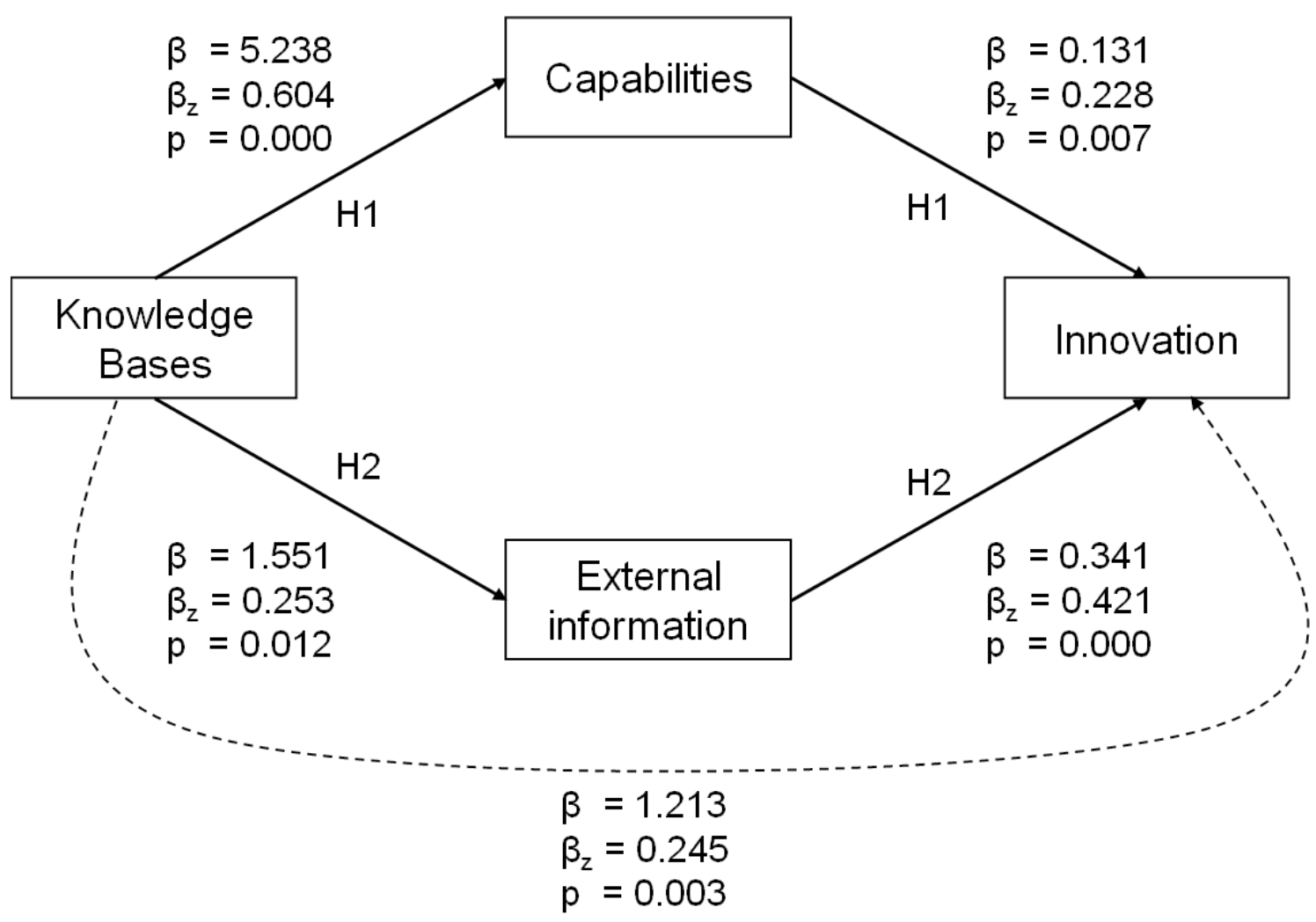

$\beta=$ coefficient $\beta_{z}=$ standardized coefficient; $p=$ rp-value; likelihood ratio $\chi 2$ of the specified vs saturated model $=3.15$; probability $\chi^{2}=0.2072$; root mean square error of approximation $=0.080 ;$ comparative fit index $=0.974$; standardised root mean squared residual $=0.042$; coefficient of determination $=0.391$

Figure 1. Results of the structural equation model, standardised 
This is an Accepted Manuscript of an article published by Taylor \& Francis Group in INNOVATION: ORGANIZATION \& MANAGEMENT on 17/01/2019, available online: https://www.tandfonline.com/doi/full/10.1080/14479338.2018.1562300.

Please, cite as: De-Miguel-Molina, B., Hervás-Oliver, J.L., \& Boix, R. (2019) Understanding innovation in creative industries: knowledge bases and innovation performance in art restoration organisations.
Innovation:
Organization
$\&$
Management,

https://doi.org/10.1080/14479338.2018.1562300

\section{Annex}

Annex 1. Descriptive statistics

\begin{tabular}{|l|r|r|r|r|r|}
\hline Variable & \multicolumn{1}{l|}{ Obs } & \multicolumn{1}{l|}{ Mean } & \multicolumn{1}{l|}{ Std. Dev. } & Min & \multicolumn{1}{l|}{ Max } \\
\hline Innovation & 89 & 4.1348 & 2.4503 & 0 & 8 \\
\hline Knowledge bases & 89 & 1.3707 & 0.4857 & 1 & 2 \\
\hline Capabilities & 89 & 5.7865 & 4.2492 & 0 & 15 \\
\hline External information & 89 & 5.3258 & 2.9839 & 0 & 9 \\
\hline
\end{tabular}


This is an Accepted Manuscript of an article published by Taylor \& Francis Group in INNOVATION: ORGANIZATION \& MANAGEMENT on 17/01/2019, available online: https://www.tandfonline.com/doi/full/10.1080/14479338.2018.1562300.

Please, cite as: De-Miguel-Molina, B., Hervás-Oliver, J.L., \& Boix, R. (2019) Understanding innovation in creative industries: knowledge bases and innovation performance in art restoration organisations. Innovation: Organization \& Management, https://doi.org/10.1080/14479338.2018.1562300

Annex 2. Alternative model estimates.

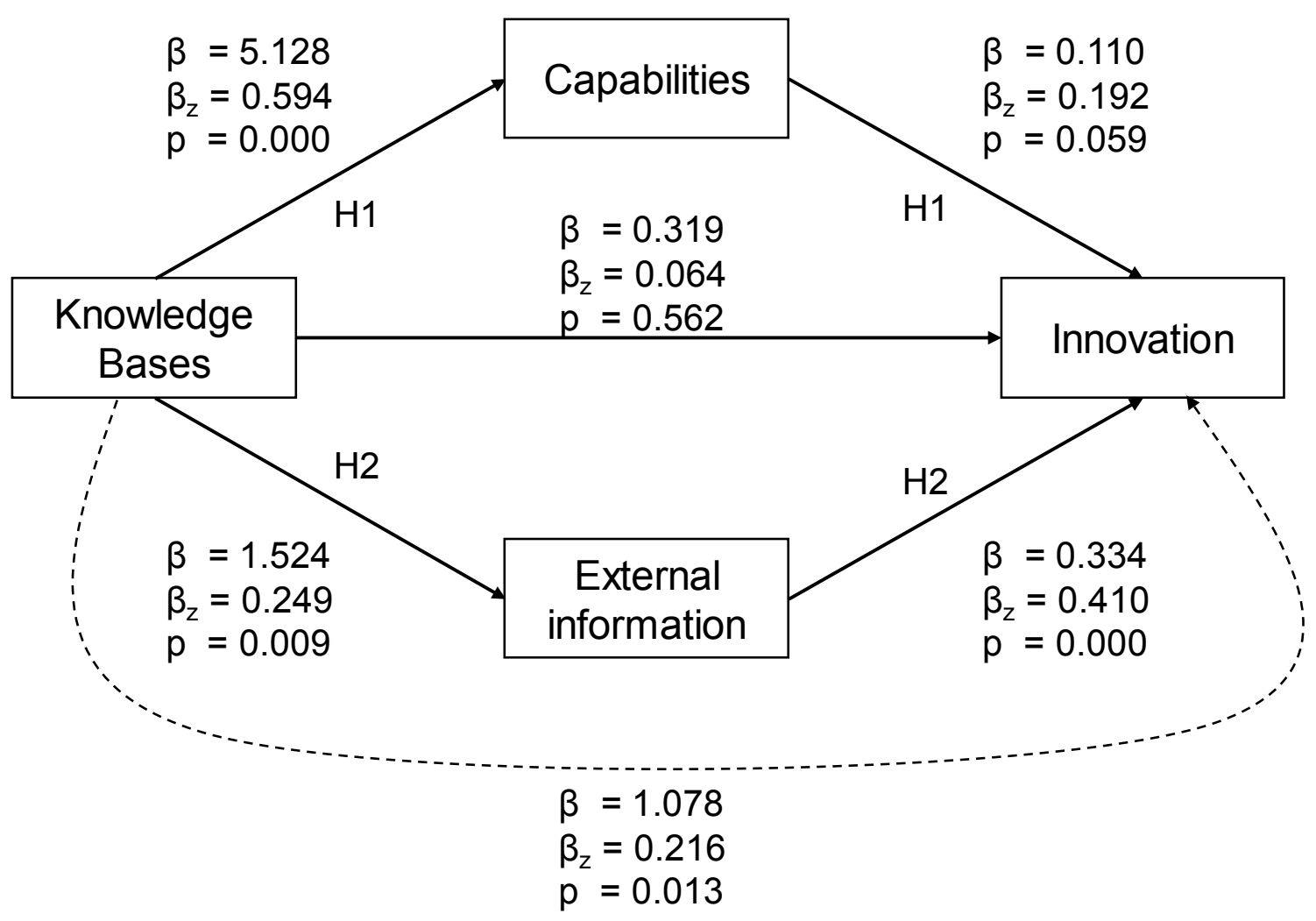

Direct effect Total effect

$\beta=$ coefficient $\beta_{z}=$ standardized coefficient $; p=p$-value

Likelihood Ratio $\chi 2$ of the specified vs saturated model $=2.82$, probability $\chi^{2}=0.098$. Root mean square error of approximation $=0.143$. Comparative fit index $=0.959$. Standardized root mean squared residual $=0.041$. Coefficient of determination $=0.382$. 